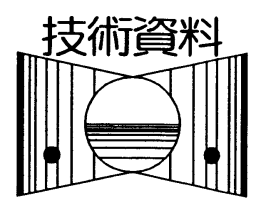

\title{
内航貨物船機関システムの 近代化実証試験*
}

$$
\begin{aligned}
& \text { 石田憲 治** 田 㴊 義 章*** } \\
& \text { 佐藤勇 } * * * * \text { 米倉 信 義 } * * * * *
\end{aligned}
$$

\section{Verification Test for Modernized Machinery System of Coastwise Cargo Vessel}

By Kenji Ishida, Yoshiaki Tabuchi, Isamu Sato, Nobuyoshi Yonekura

At present, the operation structures and technical developments of coastwise Liners are facing a turning point.

Since early 1997, the modernization of ship machinery system of a 499gross tonnage coastwise steel-cargo vessel is designed by the Modernization Committee of Coastwise Vessels and subsidized by the Ship and Ocean Foundation.

As design concepts of the modernization, modular fabricated machinery units, an integrated automatic control system of engine room machinery at the bridge and an inverter control system of sea water cooling pump, drainless measures, a combined use electric generator for the bow-thruster are mainly adopted.

Effectiveness of this modernization project is surveyed during the verification test from February 1997 to March 1998.

As a result, modular fabrication contributed to reduce the construction period and cost, the drainless mea sures contributed to reduce the workload and cleaning time for the engine crews, and the inverter system saved the total electric consumption.

This verification test apparently proposes for considerations of the modernization for the coastwise vessels from financial, technological and workload points of view.

\section{1. まえがき}

現状の内航海運界は, 制度面, 運航形態面及び 技術面で転換期にあるといえる.

特に, 船舶の機関システムには地球環境対策， 省エネルギー対策，省人化／安全性対策に加え， 信頼性向上が強く要求されるようになってきた。 同時に，この様な状況下にある内航船の就航に関 して, 各界の理解が得られるようになってきた。 平成 9 年度に(財)シップアンドオーシャン財団 以

*原稿受付 平成 11 年 2 月 22 上

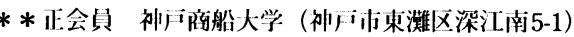

***正会員 阪神内燃機工業株式会社（明石市貴䗁5-8-70）

****エヌケーケー物流株式会社（川崎市川崎区浜仃 1-11-1)

*****正会員 MECエンジニアリングサービス株式会社（公易 市中区江波沖叮 5-1)
下 S \& O 財団) の補助事業として, 総トン数 499 トン型鋼材運搬船の実証試験が行われ，本船の機 関システムに関して設計コンセプト及び実証実験 から得られた結果を紹介する。

\section{2. 近代化機関部とは}

『内航船の近代化』と言われて 10 年近くになる が，その定義は公的に定まったものではなく，現 在の船舶の運航形態や, 機関システムの性能等を 向上させることを総称している.

今回の実証船建造に当たっては，S\& $O$ 補助事 業以外の項目についても機関システムの近代化の ために，造船側でも企画段階より検討が繰り返さ れた．検討にあたっては，運航の就労体制や港湾 事情も考慮に入れた。 
つまり，『一部の船主でなく，海運界全体に受け 入れられる近代化』を目指した。

\section{1 内航船の現状}

日本の沿岸を航行する内航船の隻数は割合から 言えば, 压倒的に総トン数500トン以下の船型が多 い.また，その多くは一次，二次のオペレーター の系列下にあって, 海上コストの削減要請を受け ている. 具体的には建造コストの削減, 乗組員の 削減, 省エネルギーの推進が求められている. 船 種, 運航形態の条件からどの項目に重点を置くか は異なってくるが, 燃料価格が比較的安価に安定 している状況下では，日常の運航，保守点検に省 力化できる機器を搭載し, 乗組員の削減を目指す ことは合理的な選択といえる。しかしながら既に 乗組員を削減している状況から, 更に乗組員一名 を削減することは非常に難しい状況であるまた， これらの対応策として, 省力化機器を搭載したい が, 機器の搭載コストが回収できないため対応を 困難にしていると考えられる.

このような周囲環境により現状の内航船機関シ ステムでは, 燃料清浄機, 潤滑油清浄機, 海水滤 器等の清掃に，日々多くの時間を費やしており， 陸上の工場の多くが, コンピューターによる自動 制御化が進められていることに比べると, 内航船 機関システムの現状は, かなり遅れている状況で ある。

\section{2 内航近代化船の設備要求}

近代化項目の決定に当たっては, 全国内航タンカ 一海運組合（ケミカル船近代化推進委員会）や運 輸施設整備事業団等で取りまとめられている内容 を基準1とした。

一方, 鋼材を運搬している船社の 18 隻に設備 要求に対するアンケートによる生の声を聞き、技術 検討会の場で討議して基本項目を決定した。

(1) 船社アンケート

(1) 20 項目程度のアンケートをオペレーターよ り各船社に郵送し，機関長が船内 機関部員の意見 や要望をとりまとめて, 返却してもらう方法を取 った. 対象船は 総トン数 199 ト $(589 \mathrm{~kW})$ ，196ト $(4,470 \mathrm{~kW})$ の 18 隻であり, 全船より回答があり, いずれも近代化への意欲を感じるものであった。

(2) アンケートの内容は, メンテナンス関連を 中心に, 日頃舶用工業界や造船界で把握できてい ない項目を主体とした。
特に，機関室機器のモジュール化を予定してい る関係上, ゴムホース使用の可否, 海水ラインの 問題点及び漏油・漏水に関する内容を主とした。

(3) アンケートの結果や要望の事例のいくつか を次に示す.

A 『海・清水ラインにゴムホースを使用す ること』に対するアンケート回答

一耐振となり良い。

一耐久性が心配

一基本性能（耐熱性, 接手部の腐食, 強度

等）を確認する必要がある.

一従来形の配管の様な腐食がないので良い.

一吸引側に使用する場合は, 外圧によりつ ぶれないようにする必要がある。

一予備ホースが必要

B【冷却海水ラインで一番困っていること は?!に対するアンケート回答

一パイプの腐食

一漏水, ゴミや貝類の詰まり

一内航船では, 浅海域で C C S を使用する 場合, 熱交換器のチューブが目詰まりす る

\section{一配管の改修が大変}

C『海水利用熱交換器の洗浄方法と期間』 に対するアンケート回答

一夏場 1 ケ月 2 回ケミカル洗浄し, 年 1 回 分解掃除 $(4,413 \mathrm{~kW}$ 級の船のみ)

また, 分解後はチューブブラシで突いて, 圧力水で洗浄していた。

一大手船社の船は，1年ごとの開放 掃除を 行っていた.

一航海中や停泊中に吸引する粗大ゴミや， 爽雑物が海水ストレーナを閉塞させるた め，一週間ごとにストレーナを開放掃除 している船もあった。

D【漏油·漏水』に関するアンケート回答 一海・清水のビルジ量は最大の船で、200?/ 日,平均的に30 401/日でルジ処理に苦労 している.

一ポンプの軸封装置の比率は、グランドパッ キン方式が $78 \%$,メカニカルシール方式が $22 \%$ あった。

E『機関の漏油・漏水を止めることが近代 化への第 1 歩と考えるか」との問いには， 
全回答が賛成であった。

F『A 重油タンクのドレン量はどの位か』の

アンケートに対する回答

一最大の船で毎当直ごと $31 /$ 回で平均的に 1

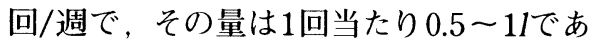
った。

前述 $\mathrm{A} 〜 \mathrm{~F}$ は，こちらからのアンケートに対する 回答例である。その他自由な意見や要望の中から 数列記述する.

一油水分離器やドレンタンクは, 複数化, または大形化とした方が良い。(3隻)

一主機関係

・主機関の馬力余裕が必要（3隻）

・発電機ブラックアウト時, 主機関が自 動停止するので, 改善する必要がある (1隻).

・操縦系統でエアー式の場合はドレンに
よる事故が多いので，対策が必要。(2 隻)

・クラッチのないCPP船は, 離着栈のア イドリング時, 海底の污泥物を摚拌し てプレートクーラーが污れやすい.（1 隻)

・夏場に機関出力を低減せざるを得ない. 改善が必要（2隻）

全てのアンケート回答は, 現状を満足したもの がなく，いずれも改善の要求が多く、船上にてメン テナンスに苦労している様子がうかがえる内容で あった。

（2）近代化への基本項目

前述のアンケートを踏まえ，技術検討会にて検 討を行い, 表 2-1に示す近代化視点と項目を選出 し，※印を除く全ての項目を採用することにした。

\section{表2-1 近代化視点と項目}

\begin{tabular}{|c|c|}
\hline 近 代 化 視 点 & 代 \\
\hline 海水ラインシの防食対策。 & 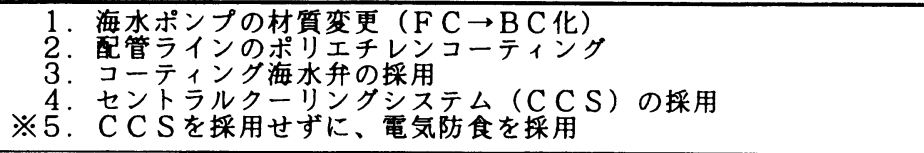 \\
\hline 機関室のノードレン化 & 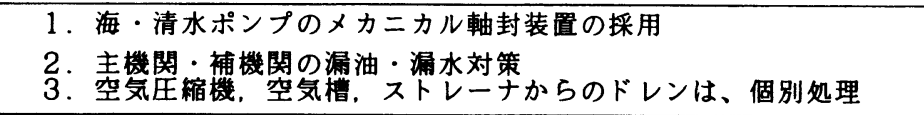 \\
\hline 省エネルギー & 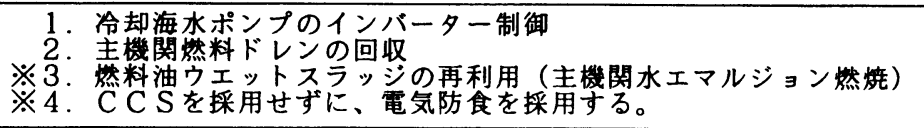 \\
\hline 性能向上 & 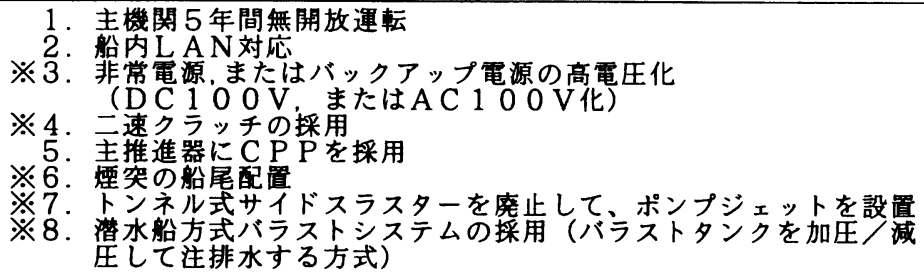 \\
\hline 省力化 & 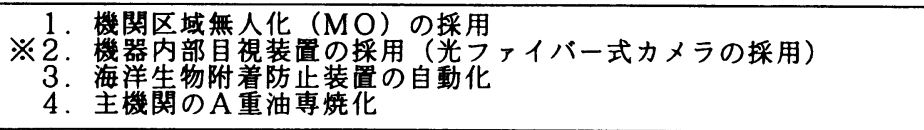 \\
\hline 建造方法の改善 & $\begin{array}{l}\text { 1. 表機関のモジュール化 } \\
\text { 2. 裓のモシュュル货の } \\
\text { 3. 船体付タシクの採用 }\end{array}$ \\
\hline 安全性の向上 & ※1. ブリッジデータの船内放送化 \\
\hline 船価低減項目 & 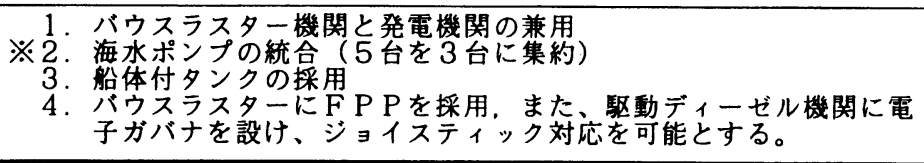 \\
\hline
\end{tabular}

※印は、今回の近代化実証試験で、実船搭載しなかった項目を示す。 
（3）技術検討会

技術検討会は, 内航船近代化委員会よりオブザ 一バ1名, 船主, 造船所及び技術支援者で構成し, アンケートの内容, MO仕様, 21 世紀の課題への 整合性や船価面を総合的に検討した.

技術検討会は，1ケ月ピッチで最終設計までの 間, 計 4 回開催した。

\section{3 近代化と経済性}

『近代化は，船価上昇を招く』と一般的に言わ れるが，船価上昇を押さえる工夫を行うことを当 初より検討した。

船価低滅のために仕様を低減するケースが考え られるが，仕様は既就航船と同等，またはそれよ り向上を狙い, 且つ船価低減が可能なものと欲張 った内容とした。

次の点で船価低減を行った。

(1) 補機用ディーゼル発電機機関とバウスラ スター駆動用機関を兼用することにより補機用デ イーゼル機関 1 台分の価格を低減した。

(2) ジョイスティック採用の場合，バウスラ スターは一般にC P P を採用するが, 本船はF P $\mathrm{P}$ を採用した。

このため, 駆動ディーゼル機関には電子ガバナ を採用した。

(3) 機関室サービスタンクは、船体付にした.

(4)一方, 運航側でも機関部員を 1 名減すこと で，夜間機関当直なしのMO船とした。

(5) 機関室の各補機類をモジュール化し，造 船所で一括搭載することで, 工程の短縮や工数の 低減を図った。

\section{3. 近代化実証試験}

\section{1 実証船一『翔陽丸」の要目}

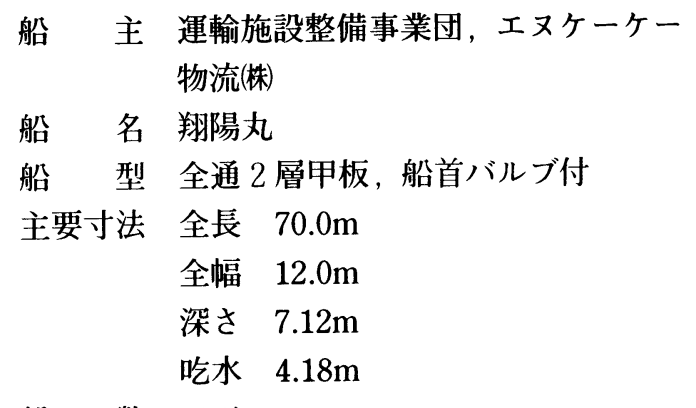

総卜ン数 497ト

載荷重量トン数 1,600 ト
主 機 関 $1,324 \mathrm{~kW}(1800 \mathrm{ps}) 1$ 基, A 重油専焼 航海速力 12.5 外

航海区域 限定近海区域（非国際）

主発電機 $180 \mathrm{kVA}, 144 \mathrm{~kW} \quad 1$ 基

主発電機用駆動機関 $160 \mathrm{~kW} \times 1200 \mathrm{rpm} \quad 1$ 基 主発電機 /バウスラスター兼用機関

$180 \mathrm{kVA} \quad 144 \mathrm{~kW}, 220 \mathrm{~kW} \times 1,800 \mathrm{rpm} 1$ 式

\section{2 近代化実証試験項目}

試験期間

(1) 平成 9 年 2 月 1 日から平成 10 年 2 月 18 日まで の約 1 年間とした。

但し，インバーター制御関連のデーターについ ては，集計期間は平成 9 年 12 月 10 日より平成 10 年 3月3日までの3ヶ月間であった.

(2) 試験項目

技術検討会で決定した各項目の有効性を確認す るために、試験項目を次の通り定めた。

A 機関室モジュールの有効性

船橋監視機関システムの信頼性の評価 のために，機関室の警報発生頻度と その 内容の調査

B 冷却海水ポンプのインバーター制御の有 効性

運転データとして, 海水温度 $\left({ }^{\circ} \mathrm{C}\right)$, イ ンバーター出力周波数 $(\mathrm{Hz})$, 電動機電流 (A) 及び清水クーラー温調弁開度 (\%)の 4 点を毎当直毎に記録

C 漏油, 漏水対策の有効性

ビルジ量（ビルジタンク内の深さを計 測)，機関や補機類からの漏油や漏水が発 見された場合は, 当直表にその内容を記 入

D 近代化項目の有効性

開放点検や長期運転をしないとその有 効性の評価が難しいことから, 近代化項 目を本船側に説明し，運転員の所見を採 取.

\section{4. 近代化事例}

一般的に,『近代化船』と称される機関システム の事例はなじみの多いものであるが，本実証試験 船に採用した項目の代表事例を次に示す.

\section{1 機関室モジュール}


中, 大型造船所では, 先行艤装のために要素ご とにモジュール化し，搭載している。しかし総卜 ン数499 999トン級の内航船で機関室モジュール をメーカーで製作し，造船所で搭載したのは本船 が初めてである。

近代化船の建造に合わせ，造船所の工法として の近代化要請もあって, 建造工程の短縮と艤装工 数低減を狙ってモジュール化を計画した。

冷却清水ポンプモジュールの外観を図4-1に示 す.

(1) 構成

各モジュールは必要なポンプ及び弁類に加え, 制御装置を共通台盤の上に一括搭載したものとし た.

このモジュールは単体で作動試験が可能なサブ システムとし, 工場試験で作動 試験を完了させ, 船内取付後, 実運転確認するのみとした。

メーカーにて製作したモジュールは，次である.
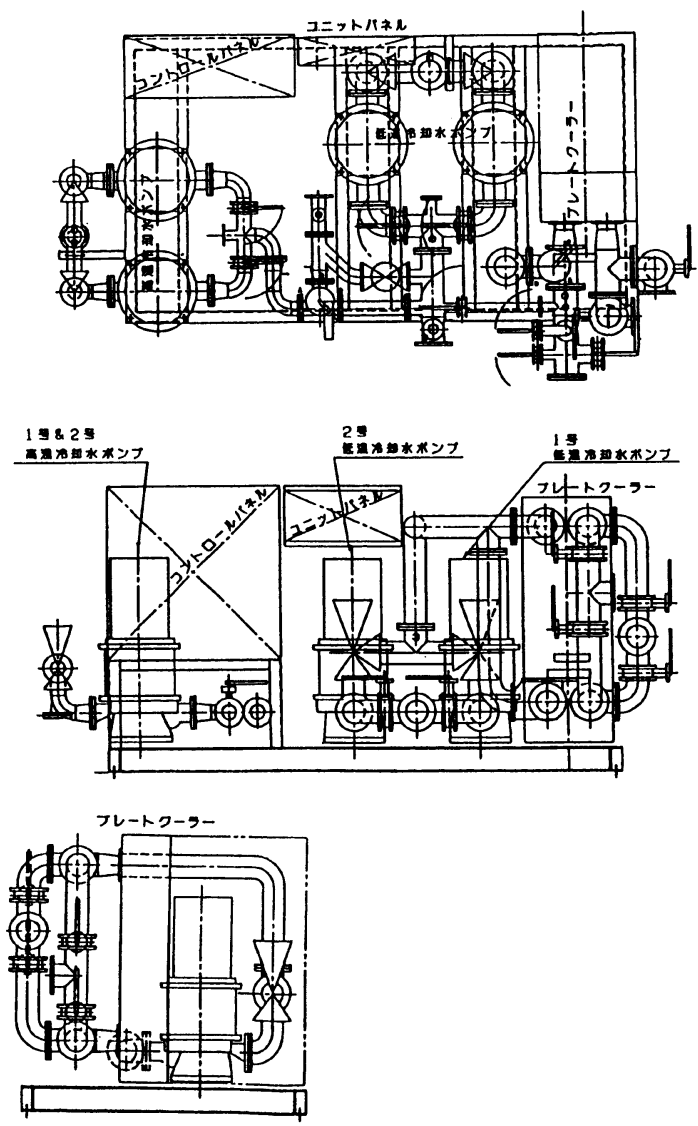

図4-1 冷却清水ポンプモジュール
冷却海水ポンプモジュール

冷却清水ポンプモジュール

ビルジ・バラストポンプモジュール

清水ポンプモジュール

空気圧縮機モジュール

潤滑油清浄機モジュール

(2) 機能

各モジュールは，その補機に要求される機能は もちろんであるが，機関室無人化及び近代化船に ふさわしいシステム内容とするために, 重要補機 モジュールには次の要素を設けた。

(1) モジュール前面で対応可能な要素

一各ポンプの手動·自動選択及び表示

一各ポンプの発停及び表示

一各ポンプの電流監視

一各ポンプの吸入, 吐出圧力監視

一各ポンプ吐出圧低下警報試験

一ポンプ吐出圧,無停電自動切替試験

(2) 各モジュールで, 船内LAN対応可能な要素 一電動機 (ポンプ) の発停制御

一電動機（ポンプ）の運転,停止信号

一ポンプ吸入, 吐出圧

一ポンプ出口温度

(バラストポンプモジュールを除く)

一温調弁開度

（冷却海水ポンプモジュールのみ）

一冷却海水ポンプ駆動周波数指令

(冷却海水ポンプモジュールのみ)

一弁開度制御及び開度指示

(バラストポンプモジュールのみ)

一弁開閉制御及び開閉指示

(バラストポンプモジュールのみ)

（3）特徵

従来工法で, 前(2)機能に記述している要素を持 つとすれば，その計画や建造には，モジュール工 法より多くの時間が必要となる.

各モジュールは，船内 L A Nのサブシステムと して, 遠隔・監視・制御しているし, 写真4-1に示 す様に, モジュールの前面で運転状況が判断可能 となる.

しかも，冷却海水ポンプモジュールの様に省工 ネルギー対応とすると共に, 漏水のないポンプシ ステムで構成している.

これらの工夫点は, 工期, 船価及び信頼性や安 


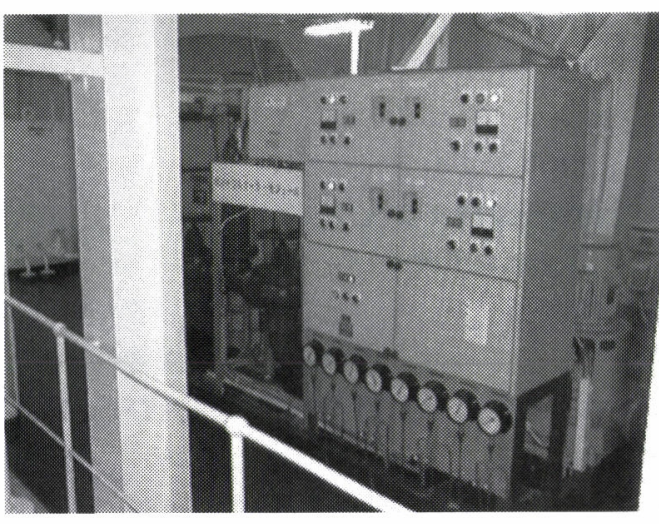

写真4-1 冷却清水ポンプモジュール

全面で効果が期待できた。

\section{2 主機関のモジュール化}

建造工程の短縮化や近代化船としての船価上昇 を防ぐために, 主機関に必要な次の機器を機関付 とし, 艤装工数の低減を図った。

一機関付とした機器一

(1) 主及び予備潤滑油ポンプ

(2) 主及び予備潤滑油ポンプ調圧弁

(3) 主及び予備潤滑油ポンプ入口逆止弁

(4) 主及び予備潤滑油出口ポンプ逆止弁

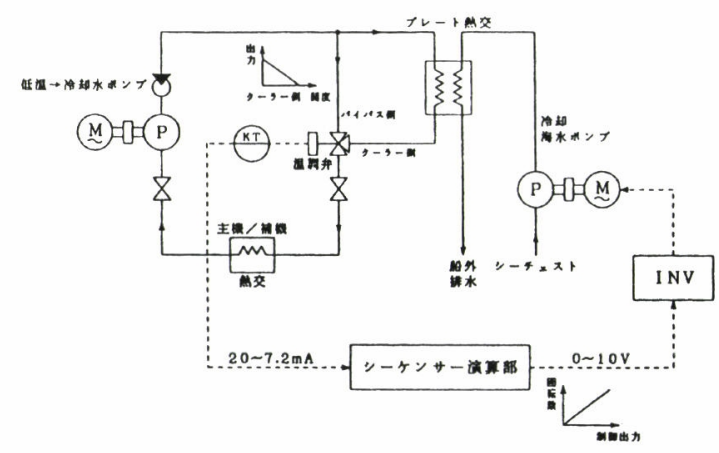

図4-2(a) 冷却海水ポンプ制御システム図

(5) 潤滑油 2 次滤器

(6) 潤滑油冷却器

(7) 潤滑油温度調整弁

\section{3 泠却海水ポンプのインバーター制御}

運送業における環境対策と省エネルギー対策は 重要課題であり, その一環として最少冷却海水量 の供給を目的として, 冷却海水ポンプの回転数を インバーターで制御した。このシステムを図4-2(a) に示す。

(1) 制御系の構成

必要冷却海水量を冷却清水ラインの温調弁より

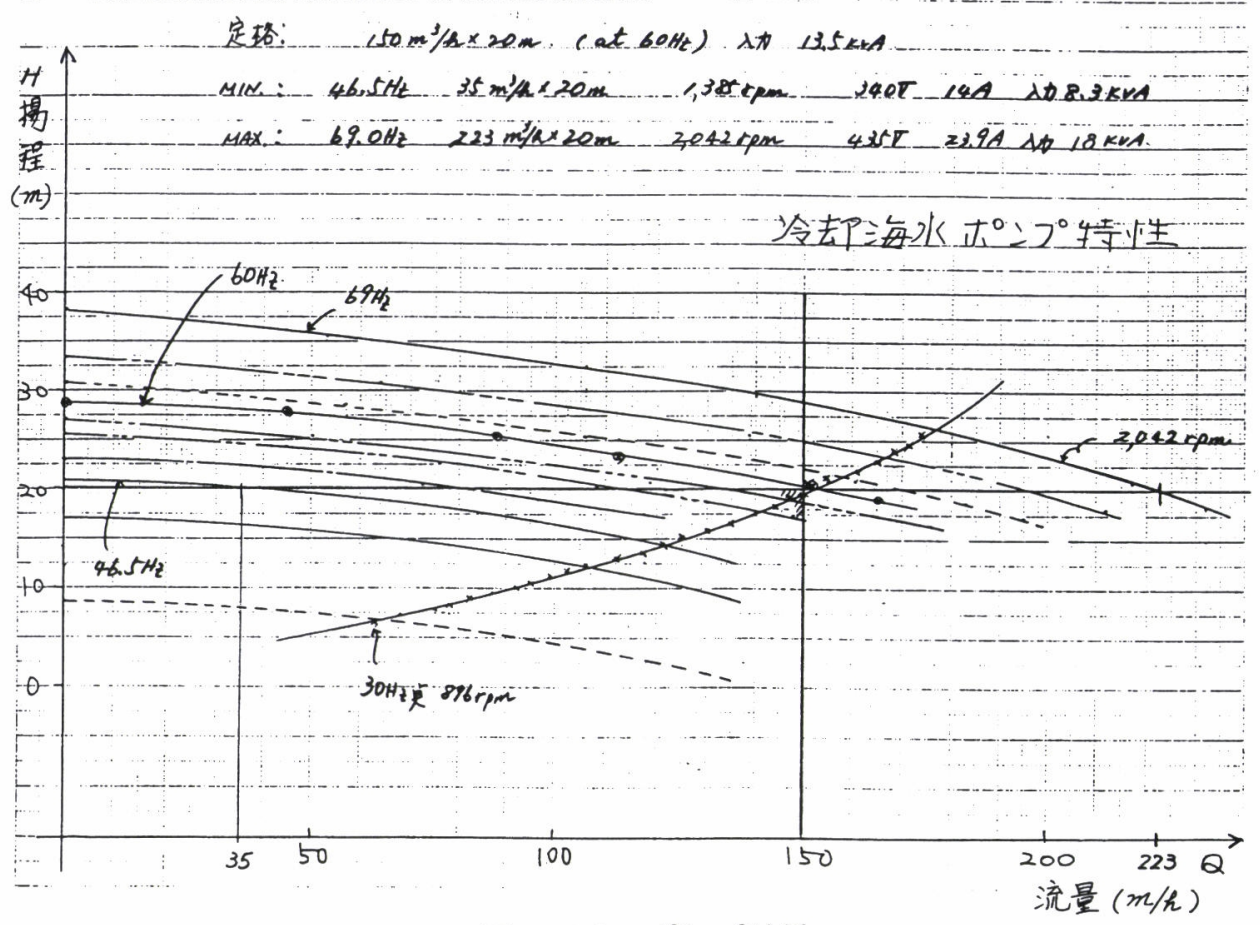

図4-2(b) ポンプ特性 
検出した。

制御はモジュール内の演算器を使用した数值制 御方式とした。

(2) 機能

(1) 航海中, 主機関の負荷や海水温度に応じて， 必要な冷却海水流量は調整されるが, 機能として 必要最少流量を供給する制御システムとした。

(2) 冷却清水ラインの温調弁の開度を入力とし て，常にその開度を90\%状態に保つようポンプの回 転数を制御した。

但し，下限は定格1,780rpmに対し，1,340rpm $(44.6 \mathrm{~Hz})$ とした.

（3）ポンプ性能

うず巻ポンプの吐出量調整は, 吐出側の弁を開 閉して行うのが一般的であるが実証実験船では， 省エネルギー効果を狙って回転数制御とした，図 4-2(b)に，回転数（周波数）を変化させた場合のポ ンプ特性（工場試験データ）を示す。

回転数(周波数)指令は、図4-2(a)に示す温調弁の 開度を空気/電気変換しシーケンサー内の数值制 御部を介して，インバーター（INV）に出力した.

\section{4 バウスラスター／発電機兼用機関}

近代化に伴い，船価の上昇は避け難いが，こ の項目はその上昇を押さえることを主目的とし て実施したものである。

(1) 兼用機関の構成

この構成を4-3図に示す.

主発電機用機関とバウスラスター駆動用機関を 兼用するために，主発電機用機関の前端に油圧ク ラッチを設けて，バウスラスターを駆動した.

一方, 発電機は片軸受, 機関直結としたためバ ウスラスター運転時に発電し，焼損の恐れがある
ためにデエキサイタ装置を設けた。

(2) 機能

この兼用機関は，機関室 MO 船の発電装置とし ての位置づけもあって，重要補機の一部でもあり、 次の機能を持たせた。

(1) 調速装置は電子ガバナ（アイソクロナス特 性）を採用し，操舵室でのジョイスティック運転 を可能にした。

(2) バウスラスターは固定ピッチプロペラ （FPP）方式とし，回転制御方式を採用した。

(3) バウスラスター運転，または発電機運転の 切替は, 操舵室コンソール上で手動切替するシス テムとした

但し，バウスラスター使用時に，他の主発電機 故障の場合，スタンバイ機能が要求されるので, バウスラスタークラッチの自動切放し装置及び同 期回転数自動保持装置を設け，数秒で発電装置に 切り替わる機能とした。

\section{5 主機関の信頼性向上対策}

原動機の故障診断や故障予知診断のために， 多くの測定計器を付加して早期に発見すること が一般的であるが，信頼性と経済性が同時に要 求される小型内航船の場合，必ずしもその要求 にマッチしていないことがある.

そこで，『故障をどの様に早期に発見するのかで はなく，どの様にして故障を起こさせないか」を 意図し，近代化船主機関の信頼性を向上させるた めに次の対策を行った。

(1) 自動化船機器の信頼性報告書2) (SRIC) (平 成 3 年度版）により, 燃焼室周りの事故が最も多 い点に着目して, ピストンリング溝のクロームメ ッキ, 排気弁及び弁座のナイモニックの対策を行

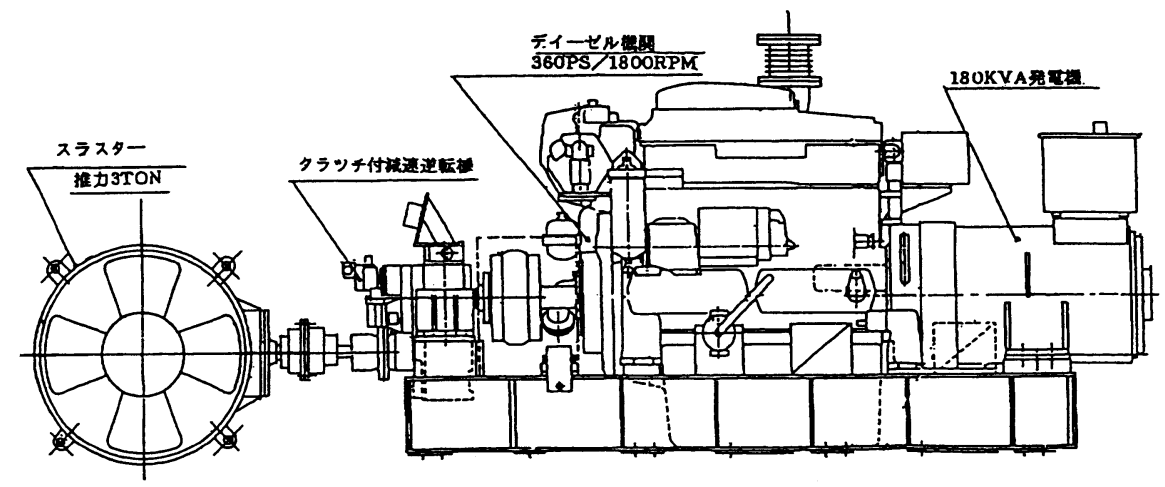

図4-3 バウスラスター/発電機兼用機関 
つた。

(2) ピストンリング及びシリンダライナ間の事 故を防ぐために，シリンダ注油用潤滑油に極圧性 向上の強化剤を $5 \%$ 添加した。

(3) 制御電源はAC $100 \mathrm{~V} / \mathrm{DC} 24 \mathrm{~V}$ とし, 交流電源 袈失時でも主機関が停止しない回路とした。

\section{6 機関室『ノードレン』化}

『漏油・漏水』に関するアンケート 2.2(1)(3) D に 示す通り, 漏油・漏水を少なくすることを，アン ケートに答えた全船より希望があった。この結果 を踏まえ, 次の要領にて, 機関室のドレンを少な くする対策を行った.

(1) 主機関燃料弁からの漏油は, 回収して使用 可能なよう, 燃料油主管の調圧弁の 2 次側に接続 し, 燃料供給ラインに戻した。

(2) 主機関のシリンダカバードレンは、動弁 腕注油や排気弁注油からのドレンであり，これを 回収して再利用できる循環方式とした。

(3) 主機関の架構扉のパッキンをOリング方式 として, 漏油対策を行った。

架構扉取付ボルト部からの漏油をなくすため， ボルト穴は貫通なしとした。

また, 架構扉附着の安全弁も漏油のないものに

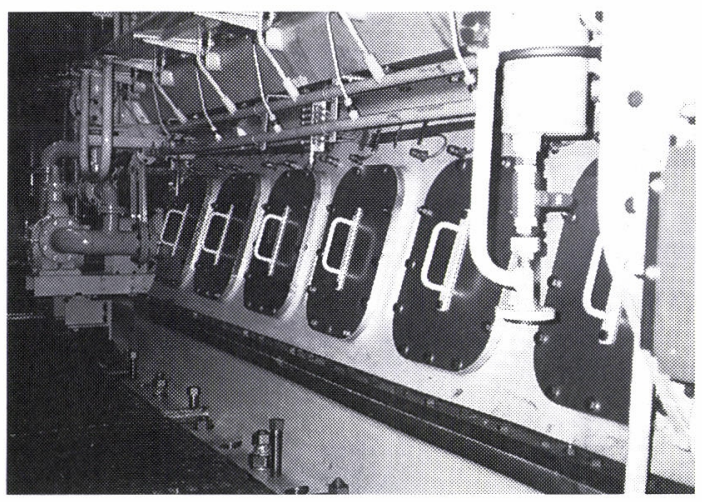

写真4-2 主機関架構扉

変更した。

(4) 主機関の動弁衝棒当金部（プッシュロード トップエンド部）に，Oリングを挿入して，動弁 衝棒に伝って流れる油ドレンを防止した。

(5) 補機関用ゴムホース部の締付バンドは二条 必要であるが, 一条の強力形（締付構造や締付バ ンドで，より強力なもの）を採用した。
(6) ポンプ類の軸封装置は,メカニカルシール 方式とした。

(7) 空気圧縮機, 空気槽及び潤滑油清浄機のド レンやスラッジは缶受けとした。

(8) 補機類で漏油や漏水が生じやすい部分 には, 製作当時より液状パッキンをも併用し, 接 手や接合部からの漏れを防いだ.

\section{7 船体付タンクの採用}

機関室には，一般にサービスタンクを設置して いるが，工程の短縮や建造コス卜低減を目的とし て、サービスタンクのうち, A 重油サービスタン ク及び潤滑油タンクを船体付タンクとした。

(1) 船体付タンクの場合, 衝突事故による油流 出の可能性もあるが, サイドタンク採用の実績が 多く, 実施した。

(2) 従来船のサービスタンクの配置と比較した 場合, サービスタンク全体を $600 \mathrm{~mm}$ ほど外板側に 寄せられ，通路が広く取れた。

\section{8 海洋生物附着防止装置の自動化}

従来の内航船では, 海洋生物附着防止装置とし て, 電気分解による次亜塩素酸ソ一ダの注入 を行ってきたが, その大半は濃度が手動調整と なっている。このため, 注入濃度によっては海水 配管が腐食孔口したり，小口径配管が海洋生物附 着により閉塞したりする故障例がある.

近代化船の機関部冷却海水システムを健全に 維持するには，注入濃度を一定にする必要があっ た。

本船の海水を取り扱う冷却海水ポンプモジュ一 ル及びビルジ・バラストポンプモジュールよりポ ンプの運転信号を出力させ, その信号に従って, 次带塩素酸の濃度を一定とする自動制御システム を付加した。

\section{5. 実証試験結果の考察}

前 4 項近代化事例を実施し，その評価について 9 ケ月間実証試験を行った結果は以下の通りであ った。

\section{1 実証船の運航実績}

試験期間，9ケ月間の運航実績は，次の通りであ った。

運航員 (機関部); 常時 2 名

航 海 日 数; 76.3 日 
航 海 距 離；22,099海里

航 海 時 間；1831.0時間

平均 速力; 11.7 ノット

主要航行区域; 福山, 川崎, 横浜, 下松, 名古屋, 堺

\section{2 近代化の有効性}

(1) 機関室モジュールの有効性

機関室モニターシステムの記録より，警報発生 頻度とその内容を集計した。

表5-1にその集計を示す.

機関室モジュール内で発生している故障は※印 を付しているが, 発生時期は就航後, 2.5 ケ及び 9〜10ケ月の2回に集中して発生している。

これらは, 就航後の初期的な故障で, モジュー 几化を阻害するものではない.

冷却清水ポンプモジュール内の温調弁（電一空 式）の電空変換器の故障が停電事故に至ったが, それ以外は特に問題となる点はなかった。
(2) 冷却海水ポンプのインバーター制御の有効性 集計期間は平成 9 年 12 月 10 日から、平成 10 年 3 月 6日までの3ケ月間である。図5-1にその運転状況を 示す。海水温度の上昇に伴い, 温調并開度は上昇 し, 合わせインバーターの出力も上昇し, 制御状 態が良好であることが確認できた。

(3) 漏油・漏水対策の有効性

機関や補機類からの漏油・漏水はなかったが， 梅雨期露点により外板面に水滴が発生し，多量の 蒸留水ドレンが発生した。しかし，この中に油分 はなく，直接に船外排出された.

空気槽からのドレンは油分を含んでいるので， 機関室ビルジ溜には落とさず，缶受けとしていた ため, ビルジタンクの污れは皆無であった.

また，燃焼系ストレーナ開放時のドレンも，ス ラッジタンクに落とさず，201缶に集積したため， スラッジタンクの污れも皆無であった。

結果として，油水分離器は1年間に 1 度も使用さ れなかった。

\section{表 5-1 機関室モニター警報集計}

\begin{tabular}{|c|c|c|}
\hline $\begin{array}{l}\text { 発 生 } \\
\text { 繁 } \\
\text { (回/年) }\end{array}$ & 警 報 項 目 & 因 \\
\hline $\begin{array}{l}518 \\
(\text { (注 1) }\end{array}$ & CPPピッチ異常 & 船体振動により翼角検出用ポテンショメータの接触不良 \\
\hline $\begin{array}{l}1001 \\
\text { (注 } 1 \text { 1) }\end{array}$ & C P P 変節異常 & 船体振動により翼角検出用ポテンショメータの接触不良 \\
\hline 18 & $\begin{array}{l}\text { 主㼄ンダー注油 } \\
\text { 沙ンラー }\end{array}$ & 原因不明（注油機本体が故障した） \\
\hline 3 & 発電機電圧異常 & A V Rの故障 \\
\hline $3 ※$ & 主機関潤滑油入口温度高 & $\begin{array}{l}\text { 潤滑油冷却器のは萛説まり } \\
\text { (時の異物混入) }\end{array}$ \\
\hline $3 ※$ & $\begin{array}{l}1 \text { 号登電機関冷却水 } \\
\end{array}$ & モジュール内温調弁故障 \\
\hline 1 & 奎機焱料油二次ろ過器 & 誤作動 \\
\hline $1 ※$ & 制御空気弁異常 & 誤作動 \\
\hline $1 \%$ & 主機高温冷却水入口温度高 & 温調弁故障 \\
\hline $1 ※$ & 主機低温冷却入口温度高 & 温調弁故障 \\
\hline $1 ※$ & 1 号空気槽圧力低 & 圧カスイッチ故障 \\
\hline 1 & 船倉ビルジウエル高 & 動摇で水が1ケ所に集中 \\
\hline $1 ※$ & $\begin{array}{l}1 \text { 号登電機温度高停止 } \\
\text { (作) }\end{array}$ & 温調弁故障 \\
\hline $1 ※$ & 警報・制御・主電源震失 & 上記停電に伴うもの \\
\hline
\end{tabular}

※印は、機関室モジュール内での故障に起因して発生した項目である。

注 1 ポテンショメータの接触不良により、警報ーリセットを綝り返したために、機関室モニター に繰り返し記録されたもの。船体振動対策工事施工後は警報なし。 

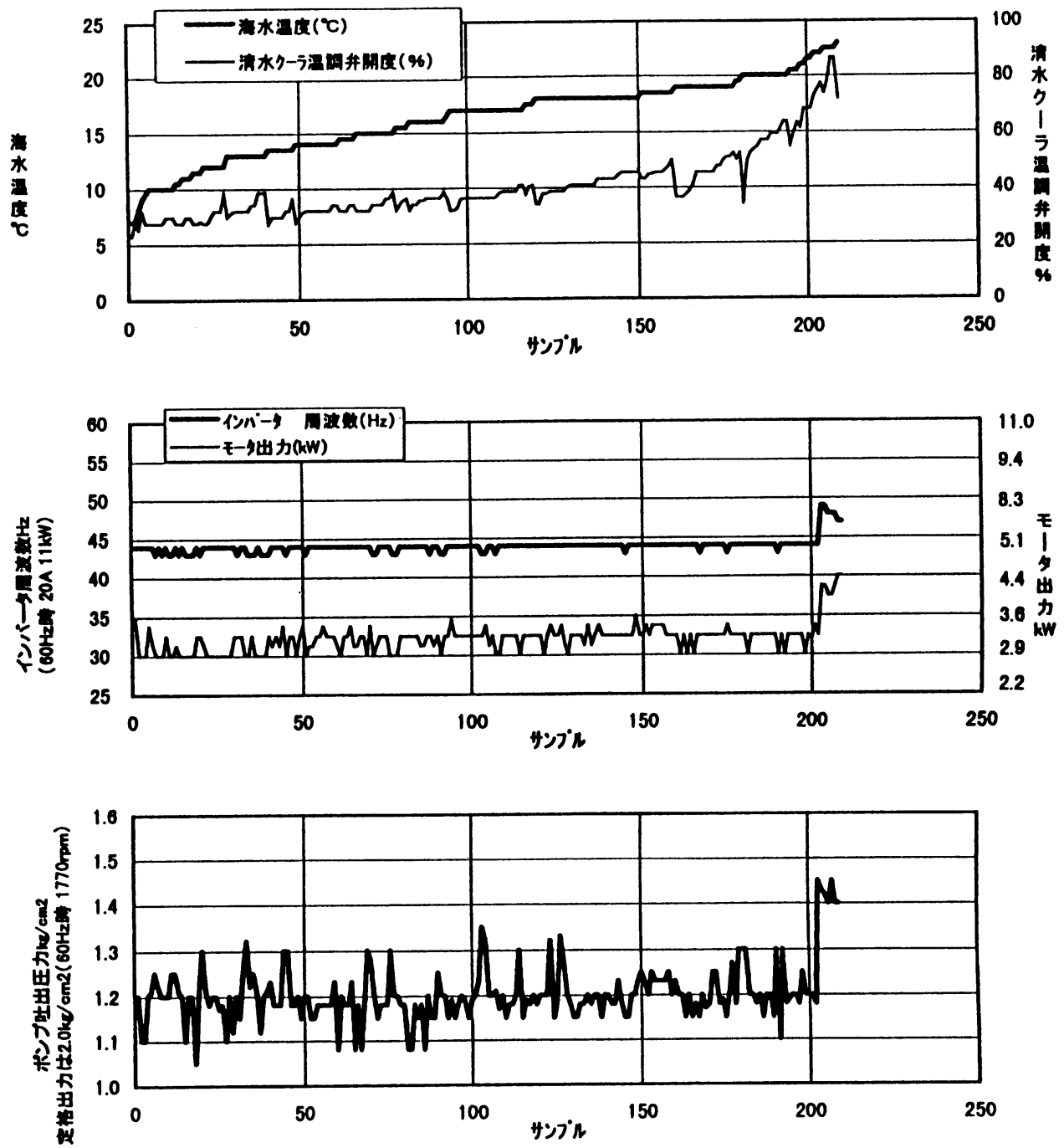

図5-1 冷却水ポンプ運転状況

(4) 近代化項目の有効性

近代化項目の有効性について，表5-2にとりまと めた。

(5) 従来船と本船との比較

運航員から聴取した評価面で, 特に興味深い点 は次の通りであった。

A インバーターで海水ポンプを低速で使用 しているためか, 本船は C P P 船で入出港 時，砂泥を巻上げているにも関わらず，ス トレーナや海水利用熱交換 器内部に堆積す る砂泥の量は他船に比べて少なかった。

B 漏油・漏水の処理に伴うメンテナンス作 業がなかったので，運転に専念できた。
C 停泊中にバウスラスター／発電機関兼 用機関を使用すると，居室は非常に静 かであったし, 電子ガバナのアイソクロナ ス特性により, 運転中の周波数調整が不要 であり，省力化できた。

D 機関室全体が広く，明るく，污れも少な く，快適な運航ができた

\section{3 今後の検討課題}

近代化事例の効果についての検討課題は次の通 りである。

(1) 機関室モジュールの構成部品の点数を下げ, 標準化を図ることによって, 建造工期上も運航側 もメリットがあり, 内航船全船に採用可能. 
表5-2 近代化の有効性

\begin{tabular}{|c|c|c|c|}
\hline 近代化項目 & 採 用 理 由 & $\begin{array}{ll}\text { 効 } & \text { 果 } \\
\end{array}$ & 今 後 の 課 題 \\
\hline $\begin{array}{l}\text { 機関室 } \\
\text { モジュール }\end{array}$ & 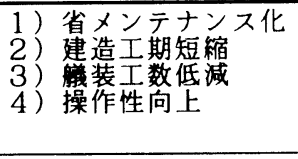 & 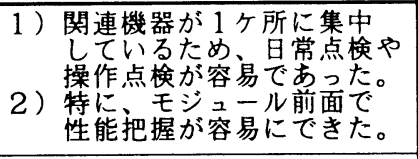 & 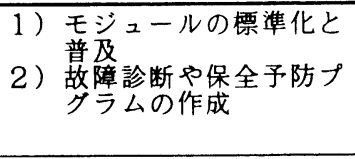 \\
\hline 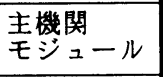 & $\begin{array}{l}\text { 1) 建造工期短縮 } \\
\text { 2) 船価低減 }\end{array}$ & & 1）普及を困る \\
\hline $\begin{array}{l}\text { バウスラス } \\
\text { 多僟併用機啭関 }\end{array}$ & 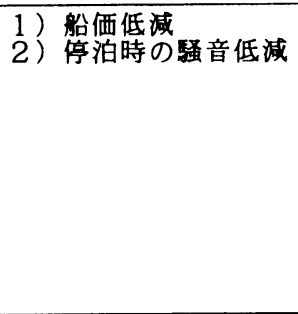 & 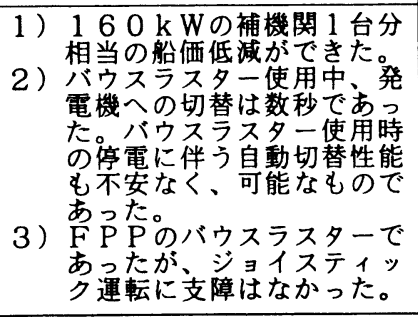 & $\begin{array}{l}\text { 1) 普及を図る。 } \\
\text { 2) 荷役中の船倉への盘音 } \\
\text { 低 }\end{array}$ \\
\hline $\begin{array}{l}\text { 冷却海水ポ } \\
\text { ジプン } \\
\text { バーター } \\
\text { 制御 }\end{array}$ & 1) 省エネル゙ー & 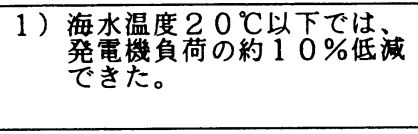 & $\begin{array}{l}\text { 1) 普及を図る。 } \\
\text { 2) 海水ポ貲の台数 } \\
\text { 統合と削堿 }\end{array}$ \\
\hline $\begin{array}{l}\text { 主機関の信 } \\
\text { 頼性向上策 }\end{array}$ & 1) 安全性向盖経費減 & & $\begin{array}{l}\text { 1） } 5 \text { 年間フ苗ーを行い } \\
\text { 対策の゙効果を評価する } \\
\text { ことか必要 } \\
\end{array}$ \\
\hline 機関室ノ一 & 1) 省メンデンンス & 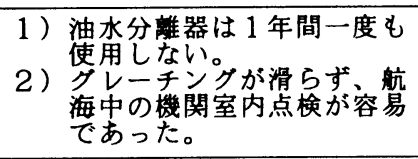 & 1）普及を困る。 \\
\hline $\begin{array}{l}\text { 船体付 } \\
\text { タンク }\end{array}$ & 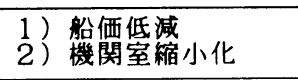 & 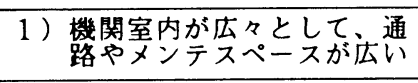 & 1）普及を図る。 \\
\hline $\begin{array}{l}\text { 海洋生物附 } \\
\text { 着防歯賣 } \\
\text { の自動化 }\end{array}$ & $\begin{array}{l}\text { 1) 省力化 } \\
\text { 2) 瀨性向上 }\end{array}$ & 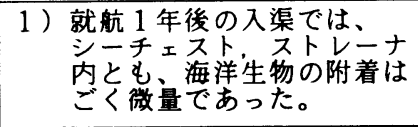 & 1）普及を困る。 \\
\hline
\end{tabular}

主機関や発電機関の出力や形式に応じて，国内 の統一を検討し, 普及を罒ることが必要である.

(2) 省エネルギーと地球環境への課題は, イン バーター利用による必要負荷の変化に対応できる 推進補機の計画や，油ビルジを発生させないため の技術要素を研究し、普及を図ることが必要であ る.

(3) 近代化各項目の今後の課題は, 表 5-2に示 †.

\section{6. 内航船機関システム近代化の検討課題}

内航船の機関システムの近代化にあたり，実施 した項目を中心に解説したが，採用されなかった 項目のうち，今後の近代化にあたり採用し，その 効果を検証する必要があると思う項目は, 次の通 りである.

\section{1 海水ポンプの統合}

内航船の大半は，用途別に設けた専用の海水ポ ンプをその目的に合わせて使用している.

ところがインバーターを採用することによっ て, 海水ポンプの吐出量を50〜150\%可変すれば, 専用のポンプを運転しなくても，インバーター駆 動ポンプより供給できることになり用途別専用ポ ンプが不用となる。従って, 海水ポンプが統合さ れ，装備合計台数が半数以下になる。省メンテナ ンスの観点からも，海水ポンプを統合配備するこ とが可能である.

\section{2 配管材と弁類}

モジュールと船内配管の統合部のゴムホースの 採用や，海水配管や弁類への新工法（ポリエチレ ンやナイロンコーティング等）を採用し，信頼性 の向上に務めることが必要である.

\section{3 ドレンの処理}


『ドレンをどの様に処理するかではなく，ど、 の様にして発生させないか』に主体を置き，対応 した.

特に燃料油のドレンやスラッジは, 可能な限り 本船内で再利用し，ドライスラッジのみ陸揚げ処 理すべきと考えている.

今回の実証試験では実船実施しなかったが，将 来の環境対策（ $\mathrm{N} ＼textrm{o} x$ 対策）と， $\mathrm{A}$ 重油サービス タンクのウエットスラッジの燃焼による省エネル ギーと省力化を目的として，本船主機関による水 10\%（容積比）エマルジョン燃焼実験を工場試運転 時に行った。

50\%負荷運転中に，A重油燃料ラインを水エマル ジョンラインに切替えて，75\%及び100\%負荷とそ れでれ約 30 分間運転したが燃焼は良好であった。 結果として，NOxの上昇と燃料消費率の改善が見 られた。

\section{4 蓄電池電源のDC100V化}

現在，海上では蓄電池による非常用電源として， DC24Vが全面的に採用されているが, 専用の蓄電 池室が必要であったり, 電圧降下による大ケーブ 儿の採用や，接触不良による作動不良等の問題が 指摘されている.

しかし，陸上の設備では，シールド形（メンテ ナンスフリー）の蓄電池を DC100V非常電源とし て，パネル内や屋内の一般区画に設置している.

内航船の場合，限られたスペースと信頼性向上 のためにも，DC100V化の検討が必要である.

\section{5 潜水船方式バラストシステム}

現行のバラストシステムは, 機関室に配置のバ ラストポンプより弁を介して, 各バラストタンク へ注・排水している.

この方式は，大きなエネルギーを必要とするう えに, 残水が $10 \%$ 位あって, 積荷を減少させて いる.

また，内航船の事故は，座礁が多く二重底内の 浸水量が大きければ，現在の ‘汭ストシステム' では，許容喫水線を越えて全損に至るケースがあ る。

一方，潜水船方式であれば，圧縮空気を投入し て，排水するので二重底外板が大破されない限り， デバラストが可能となり，全損事故が防げる.

\section{6 二速クラッチの採用}

離着栈時, 船体を横移動させる場合, 高性能舵
と推進器は C P P を組み合わせることが一般的で ある。

CPPの主目的は，上記以上にトルクリッチ対策 や，ジョイスティック採用に伴う性能向上等の利 点もあるが，船価を抑え，CPPと同程度の性能を 持たせるには，多くの漁船で採用されている二速 クラッチの採用も考えられる.

\section{7 煙突の船尾配置}

内航船の煙突は, 操船室の直後に配置されてい るのが一般的であるが, 後方の視界を阻害してい る．煙突を船尾配置にすることによって，操船室 の広視界化みならず，居住区画の構造や環境改善 に効果が期待できる.

環境対策の一環として，Nox や煤塵量の削減 に合わせ，煙突の船尾配置を検討すべきである.

\section{8 ブリッジデーターの船内放送}

小人数乗組の内航船の場合, 航海データや機関 データを，乗組員全員が把握することは安全性の 向上にとっては，大切な要素である.

ECDISのデータ，レーダー映像や機関システム の故障情報等は既に集約されており，これらをテ レビシステムを使用して，船内放送するシステム を構築すれば，省力で安全性向上も期待できる。

\section{9 熱交換器・ストレーナ内部目視}

内航船は，港湾の浅い場所まで出入りすること が多く，特に C P P 船はクラッチがないため係留 時に海底の砂泥を巻き上げ，熱交換器やストレー ナを目詰まりさせることが多い.

そこで，光ファイバー式カメラを使用して，熱 交換器等の機器の内部を目視すれば, 洗浄のタイ ミングや洗浄程度が把握できるため, 省力化や安 全性が向上すると考えている.

\section{7. おわりに}

実証試験完了後に，本船乗組員より，「このよう な近代化船に乗船したら従来船には乗れないな。近 代化船は性能面もさることながら，メンテナンス も楽であった」との感想があった。

今回の近代化事例は，公知の項目に改善を加え たものが大半ではあるが，海運界や海員へ益する 事項であることが理解されたと言える.

採用されなかった項目と課題は，今後機会を得 て実証するが，近代化の目的や技術的背景が，内 
航船の建造·運航に少しでも役立てば幸いである。

\section{参 考文 献}

1) (財) $\mathrm{S} \& \mathrm{O}$ 財団：平成 9 年度

内航船近代化の為の実証試験事業報告（平成 10 年 3 月）

2) (財) S\&O 財団: 平成 3 年

自動化船機器の信頼性調査報告書

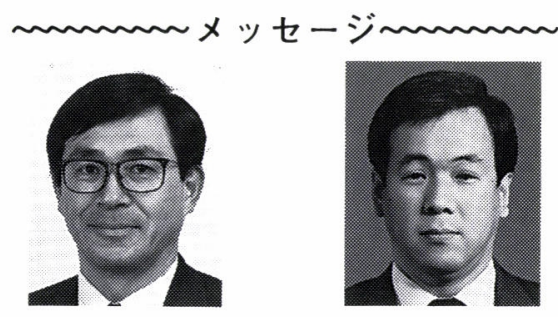

石田憲治

田 㴊 義 章
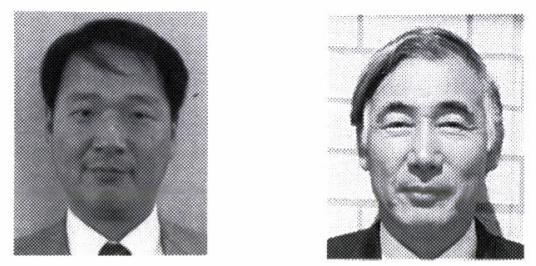

佐 藤勇

米 倉 信 義

本船は，平成10年度シップオブザイヤー準賞に輝いたこ とは，計画段階より携わった者として本当にうれしく思っ ている。一人よがりでなく，海運界に受け入れられる近代 化船一そして船価を抑え，21世紀でも通用する船に近づい たと考えている.

新しい試みをする場合, 多くの慣例とぶつかるのは常で, 大胆, 且つ繊細な計画の基, 多くの理解者の協力がなくて は近代化は進められないので今後とも皆様の御支援をお願 いします。 